\title{
PERANCANGAN VISUAL APLIKASI PELAYANAN PENGANTARAN GALON DI KOTA MAKASSAR BERBASIS ANDROID
}

\author{
Haerianah Haeruddin, Sukarman B, Irfan Arifin \\ Desain Komunikasi Visual Fakultas Seni dan Desain Universitas Negeri makassar \\ haerianahaeruddin@gmail.com \\ sukarman.b@unm.ac.id \\ irfan.arifin@unm.ac.id
}

\begin{abstract}
ABSTRAK
Penelitian ini bertujuan merancang aplikasi digital yang mempermudah transaksi dalam pembelanjaan isi ulang galon, mengutamakan tampilan visual dengan desain yang modern dan komunikatif yang mengangkat konsep visual yang modern dengan gaya flat design. Jenis penelitian adalah perancangan desain dengan teknik pengumpulan data dilakukan melalui wawancara, observasi, studi pustaka, dokumentasi. Dalam penelitian perancangan ini setelah data dikumpulkan dilakukan telaah analisis yang mencakup gaya-gaya desain, layout, tipografi, dan warna sehingga menciptakan konsep yang diinginkan. Penelitian perancangan menghasilkan dua prototype aplikasi yaitu aplikasi khusus untuk penjual galon dan aplikasi untuk konsumen yang akan membeli product yang di tawarkan dengan desain visual yang digarap secara khusus dengan brand "kepercayaan". Selain media utama, dalam perancangan ini juga didukung oleh media pendukung untuk mempublikasikan aplikasi tersebut.
\end{abstract}

Kata Kunci: Startup; Desain; Aplikasi Digital, Depot Air Minum

\section{PENDAHULUAN}

Saat ini teknologi sangat berkembang pesat. Kemajuan teknologi dan komunikasi membuat kebutuhan masyarakat akan informasi yang cepat dan tepat semakin tinggi. Keadaan ini semakin mendorong manusia untuk terus melakukan berbagai macam percobaan dan penelitian untuk pengembangan maupun penemuan cara-cara baru guna memberikan manfaat lebih untuk mempermudah manusia dalam menjalankan aktivitasnya.

Pada tahun 2015 dan 2016, mulai masuk aplikasi jasa berbasis online di Kota Makassar, aplikasi tersebut merupakan aplikasi Ojek Online yang menawarkan kemudahan dalam bertransaksi karena biaya tarif angkutan sudah di tetapkan dan di setujui terlebih dahulu oleh penumpang hampir tidak ada tanda-tanda yang menunjukkan bila layanan ojek online akan menjadi sesuatu yang besar tahun ini. Bisnis transportasi ondemand memang sudah mulai dikenal, salah satunya karena kontroversi kehadiran Uber di Indonesia. Setahun berselang, berkat kehadiran aplikasi GO-JEK pada bulan Januari dan layanan Grab Bike empat bulan kemudian, ojek online langsung menjadi salah satu bisnis startup yang paling populer di Indonesia. Persaingan dua startup tersebut kemudian memicu munculnya startupstartup lain yang juga bergerak di bisnis yang sama, $\quad$ seperti Blu-Jek, TopJek, LadyJek, dan Jeger Taksi. Bagaimana sebenarnya layanan ojek online berubah dari layanan yang tidak dikenal menjadi sebuah layanan yang sangat populer sepanjang tahun ini. Semua itu tak lupuk dari konsep visual dan promosinya. Membuat tampilan sedemikian rupa bukan hanya konten yang ada pada aplikasi yang dibutuhkan tapi tampilan visual yang mendukung dan menarik.

Terlepas dari perkembangan teknologi, startup, dan persaingan bisnis yang semakin ketat di kota makassar, usaha-usaha kecil kini mulai tersingkirkan dan mengakibatkan lebih banyaknya pengangguran. Seperti depot air minum usaha kecil yang dipandang kurang berkembang bahkan jika diberikan sedikit 
sentuhan teknologi maka bisa jadi usaha itu terangkat dan memiliki lapangan kerja yang luas. Depot air minum atau jasa galon adalah produk yang dibutuhkan tapi pemesanannya masih kurang efektif bahkan dalam pemesanan memiliki beberbagai masalah mulai dari pesanan galon yang lama di antar, tidak memiliki pulsa untuk memesan, serta kurangnya informasi lokasi depot air minum.

Sebelum lebih jauh mengangkat masalah ini lebih dahulu dibuatkan kuesioner melalui google form, ternyata banyak masyarakat di kota Makassar menggunakan jasa galon dan kebanyakan dari mereka membeli galon dengan cara menelpon dan sms, ternyata banyak yang memiliki kendala masalah pengantaran galon, sehingga disimpulkan banyak yang mengalami hal serupa. Berdasarkan pertanyaan yang diajukan, beberapa pendapat menginginkan adanya jasa pengantaran galon dengan persentase \pm 60.9 $\%$ menyetujui ini. Pada play store ternyata belum ada jasa pengantaran galon di Kota Makassar, ini merupakan kesempatam membuat inovasi baru karena pada saat ini masih jarangnya aplikasi pada perangkat bergerak yang memanfaatkan teknologi untuk melakukan pemesanan, pencarian dan pengantaran pembelian galon, sehingga masih banyaknya yang mengalami kesulitan dalam mengetahui informasi tempat-tempat penjualan galon maupun pengantaran galon.

Dengan alasan tersebut, ide untuk membuat suatu aplikasi yang dapat digunakan pada perangkat bergerak berbasisi android untuk mencari lokasi pembelian serta pengantaran jasa galon yang berada di kota Makassar. Dengan menggunakan metode Location Based Service (LBS) (Djafar, 2015) akan memberikan layanan pada pengguna aplikasi untuk mengetahui dimana lokasi rumah penjualan galon berada. Penelitian ini lebih menekankan pada tampilan visual pada perancangan aplikasi. Menurut Michael Christiawan dalam buku DEKAVE karya (Tinarbuko, 2015) "Desain yang bagus itu desain yang memenuhi unsur dasar dari segi desain, seperti: tipografi yang mudah terbaca dan sesuai fungsinya, warna yang sesuai, dan gambar yang memang berfungsi dengan semestinya. Didukung pula dengan studi public apabila desain ingin diluncurkan ke public, supaya desain yang dihasilkan bisa diterima oleh public dengan baik. Tidak hanya idealisme sang desainer. Dalam buku yang sama Mia Candra komunikatif. Maka di rancanglah sebuah perancangan yang berjudul: "Perancangan Visual Aplikasi Pelayanan Pengantaan Galon di Kota Makassaar Berbasis Android"

Konsep pemasaran perlu dipahami untuk pembuatan strategi yang tepat. Dalam menjalankan sebuah perusahaan pastinya pemahaman akan seluk beluk konsep pemasaran memang sudah sepatutnya diketahui. Konsep ini merupakan salah satu konsep tertua yang dipakai oleh para penjual. Namun konsep produksi ini tidak dapat dikatakan ketinggalan jaman, konsep ini masih dapat bermanfaat dalam beberapa situasi. Sebagai contoh, pembuat smartphone dari Cina mendominasi pasar smartphone global. Mereka akan sangat kompetitif dan sensitif terhadap harga, baik itu upah buruh yang rendah, efisiensi produksi yang tinggi, dan distribusi massal (Kotler \& Gary Armstrong, 2008).

Graf adalah himpunan objek yang terdiri dari simpul dan sisi, simpul pada graf dapat berupa titik sedangkan sisi adalah objek pada graf yang menghubungkan simpul. Graf kini telah diaplikasikan untuk banyak hal, seperti pembangunan jalur kereta api, jalan lintas kota, distribusi produk bisnis, senyawa kimia, hingga representasi data, penggunaan graf dalam merepresentasikan data memungkinkan data lebih mudah dipahami dan diolah (Rudi, 2016).

Sistem informasi adalah suatu sistem didalam suatu organisasi yang mempertemukan kebutuhan transaksi harian, mendukung operasi, bersifat menejerial dan kegiatan strategi dari suatu organisasi, menurut Leitch dan Davis dalam (Jogiyanto, 2017)

Style desain yang sedang populer saat ini seperti Vintage design dan Flat design bahkan terinspirasi dari style desain yang terkenal dulu seperti 'Victorian Style Design (18371901)', 'Swiss / International Design (19401980)' dan lainnya. Berikut adalah daftar style desain grafis yang disusun berdasarkan tahun terciptanya style tersebut, bukan daftar definitif melaikan pilihan dari beberapa style desain yang paling umum dan populer pada masa-nya. Anda bisa menggunakan daftar ini 
sebagai inspirasi desain anda dan sebagai pemahaman dasar tentang gaya desain grafis yang umum digunakan, bagaimana style tersebut tercipta dan apa perbedaan dari style desain tersebut (Maki, 2017)

\section{METODE PENELITIAN}

Teknik pengumpulan data merupakan faktor penting demi keberhasilan perancangan yang dilakukan. Dalam penelitian, pengumpulan data dilakukan untuk memperoleh informasi yang dibutuhkan tentang objek yang menjadi sasaran dalam rangka mencapai tujuan penelitian.

Observasi pada perancangan ini dilakukan untuk memperoleh data primer. Observasi dilakukan pada masyarakat Makassar terutama pada anak kost yang sering membeli dan menggunakan jasa galon. Observasi bertujuan untuk mengetahui seberapa efektif pemesanan galon menggunakan telpon atau sms serta mengetahui apa halangan atau hambatan sehingga pemesanan galon biasanya lama diantarkan.

Teknik wawancara pada tahap ini, dilakukan secara tatap muka atau tanya jawab langsung untuk memperoleh data primer. Wawancara dilakukan untuk mendapatkan informasi yang dibutuhkan. Data diperoleh dari masyarakat Makassar terutama anak kost, penjual dan kurir galon. Wawancara ini bertujuan untuk mengetahui faktor penyebab terhambatnya pengantaran galon.

Studi Pustaka pada perancangan ini digunakan untuk memperoleh data sekunder. Data yang diambil dari beberapa sumber buku terkait dengan perancangan aplikasi dan desain grafis. Selain itu, juga dilakukan dokumentasi pengambilan gambar terhadap proses perancangan, sasaran atau objek penelitian. Pengambilan dokumentasi bertujuan untuk mendukung data-data sebelumnya. Dokumentasi akan dilakukan pada saat turun kelapangan dan mengobservasi objek yang akan disasar.

Keempat tehnik pengumpulan data itu di gunakan dengan maksud mengetahui seberapa efektif pemesanan galon menggunakan telpon atau sms serta mengetahui apa halangan atau hambatan, sehingga pemesanan galon biasanya lama diantarkan.

\section{HASIL DAN PEMBAHASAN}

Perancangan dilakukan dengan pendekatan analisis SWOT (Strenght, Weaknes, Opprtunity, Threat. Untuk mendapatkan hasil analisis secara jelas dan tepat maka pada perancangan ini analisis dibagi dalam dua bagian yakni analisis obyek dan analisis media.

\section{Analisis Obyek}

1) Strenght (kekuatan)

a) Dengan menggunakan aplikasi akan lebih memudahkan penggunanya.

b) Dalam aplikasi harga dan tempat sudah tersedia.

c) tidak perlu lagi resah akan pengantaran galon yang memakan waktu.

d) Belum adanya aplikasi yang menggunakan jasa jual beli galon dan pengantarannya.

e) Mengetahui harga sebelum membeli.

f) Dapat mengetetahui lokasi dan keberadaan pengantar galon.

g) Memiliki pelanggan yang tepat atau distributor.

2) Weakness (kelemahan)

a) Laba yang akan diperoleh depot galon tidak bisa diprediksikan

b) Harus membranding dan mempromosikan aplikasi pelayanan pengantaran galon dari awal hingga di kenal masyarakat.

3) Opportunity (kesempatan)

a) Memiliki peluang dipasarkan dan bersaing dengan aplikasi sejenis

b) Membuka lapangan kerja

4) Threat (ancaman)

Pemilik depot air minum dimakassar belum bisa memanfaatkan teknologi yang semakin hari semakin berkembang

\section{Analisis Media}

1) Strength (kekuatan)

a) Perkembangan teknologi sangat berkembang pesat.

b) Kemajuan teknologi dan komunikasi membuat kebutuhan masyarakat akan informasi yang cepat dan tepat semakin tinggi 
c) Mempunyai jangkauan yang sifatnya global, sehingga informasi yang disajikan dapat diakses di kota makssar.

d) Dengan menggunakan internet, tidak perlu menggunakan banyak pulsa menelpon depot galon yang tersedia

e) Dengan menggunakan internet, dapat mengetahui depot galon yang buka di tempat yang terdekat

f) Informasi tersaji dapat diakses 24 jam.

2) Weakness (kelemahan)

a) Aplikasi tidak dapat langsung diketahui jika tidak ada media pendukung yang mempublikasikan keberadaannya.

b) Keterbatasan kecepatan internet yang berbeda-beda pada tiap pengakses, di mana pengakses yang mempunyai kecepatan internet rendah tentu akan mengalami ketidaknyamanan karena membutuhkan waktu yang lebih lama untuk membuka dan memesan galon dibandingkan dengan pengakses yang mempunyai kecepatan internet tinggi.

c) Penggunaannya relatif tidak praktis karena konsumen harus menyalakan perangkat mobile dan menyambungkannya dengan jaringan internet.

3) Opportunity (peluang)

a) Pertumbuhan jaringan internet kini semakin pesat siring dengan kebutuhan masyarakat akan informasi dan semakin murahnya biaya yang harus dikeluarkan, dengan begitu jumlah pengguna internet akan semakin banyak dari waktu ke waktu dan ini akan menjadi potensi keberhasilan situs web untuk menjangkau semakin banyak orang.

b) Popularitas smartphone ini juga diikuti oleh banyak diproduksinya ponselponsel konvensional yang meniru bentuk-bentuk dan fasilitas yang ada pada smartphone seperti koneksi wifi dan kemampuan untuk selalu tersambung di internet.

4) Threat (ancaman)

a) Koneksi internet nirkabel pada perangkat mobile tergantung pada kekuatan sinyal operator jaringan ponsel. Hal ini menyebabkan lokasi geografis dan kondisi cuaca dapat mempengaruhi kecepatan koneksi internet.

b) Semakin berkembang pesatnya teknologi membuat pesain aplikasi serupa bermunculan.

\section{Konsep Desain}

Karya yang dibuat adalah desain visual aplikasi digital pelayanan pengantaran galon dengan berbasis android di Kota Makassar dengan mengangkat Konsep "Kepercayaan" pada perancangan ini. Desain yang akan dibuat adalah tampilan visual pada aplikasi dengan menggunakan gaya desain yang simple dan mudah dipahami oleh orang yang melihat tampilan tersebut. Adapun gaya yang akan diterapkan pada perancangan visual aplikasi galon tersebut ialah gaya Flat Design dimana gaya desain ini lebih minimalis, dengan pemilihan warna yang sesuai. Adapun tipografi yang akan digunakan pada logo ialah Typo Hoop Demo Font, dimana font ini akan menjadi kombinasi yang simple serta terlihat modern sehingga menghasilkan tampilan visual yang menarik dan mudah dipahami.

\section{Konsep Kreatif \\ Sumber Inspirasi}

Tampilan visual dari aplikasi Grab banyak menjadi sumber inspirasi dalam perancangan visual aplikasi pelayanan pengantaran galon ini. mulai dari tata letak layout dan perpaduan warna.

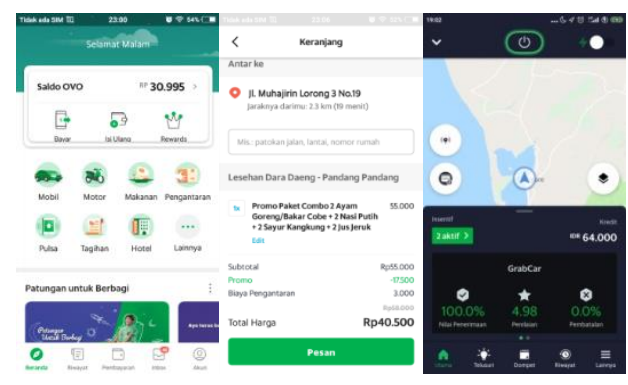

Gambar 1 Sumber Inspirasi

\section{Tipografi}

Dalam perancangan digunkan dua jenis font yaitu font untuk kebutuhan logo dan font untuk keperluan isi rancangan aplikasi. Adapun Untuk Body Text menggunakan jenis 
font Sans Seriif dan Untuk
menggunakan font Typo Hoop Demo

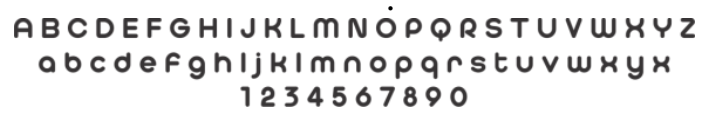

Gambar 2 Font Typo Hoop Demo

\section{Warna}

Logo, tombol dan konten-konten lainnya yang sejenis dalam bentuk grafis, akan menggunakan warna tersier yang bersifat netral yang dikombinasikan dengan warna yang agak kontras pada objek yang dianggap perlu ditekankan, hal ini bertujuan agar rancangan yang dibuat menjadi lebih hidup dan tetap seimbang. Warna-warna yang digunakan adalah warna yang dapat mewakili atau menimbulkan rasa kepercayaan antara pengguna dan aplikasi, dan akhirnya warna yang terpilih ialah warna biru dimana warna biru bermakna kepercayaan, Damai, Tenang, Keseriusan, dan Keyakinan (Heri, 2017), bukan hanya itu warna biru juga diambil dari warna air. Sedangkan untuk background dominan akan menggunakan warna netral semisal putih agar terlihat lebih rapih, bersih, elegant dan tetap modern. Setelah biru menjadi warna utama dalam perancangan ini, warna biru di pecah lagi menjadi dua warna yaitu warna biru mudah dimana warna bening dari air terbiaskan dengan warna wadahnya yaitu galon sehingga jadilah warna biru muda dan warna kedua yaitu warna biru tua yang diambil dari warna galon. Dari segi psikologi Warna, warna biru juga bermakna kepercayaan, Damai, Tenang, Keseriusan, dan Keyakinan.

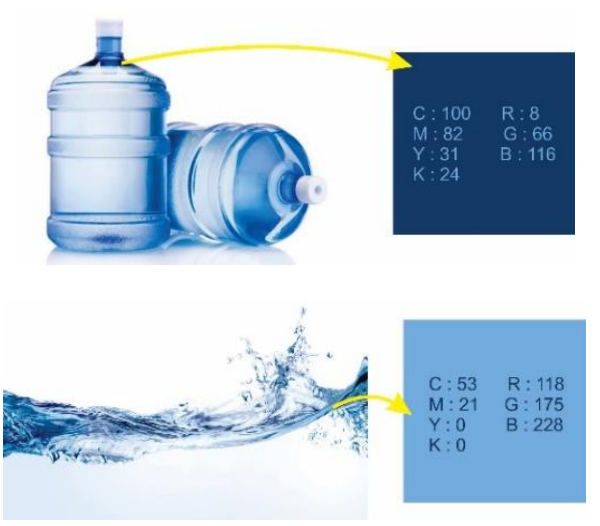

Gambar 3 Warna

\section{Desain Logo}

Dari Thumbnail yang telah disusun memunculkan beberapa kata kunci untuk membuat branding logo ialah, cepat, dapat dipercaya, simple serta dibutuhkan, dari keempat kata kunci tersebut akhirnya dipilih satu yaitu kata kunci "Dibutuhkan". Mengapa dibutuhkan dipilih sebagai kata kunci, untuk pembuatan logo karena air memang sangat dibutuhkan oleh makhluk hidup. Air bisa diartikan sebagai sebuah sumber kehidupan dan tanda dari adanya kehidupan. Mengapa menjadi sumber kehidupan karena setiap makhluk hidup di muka Bumi ini memerlukan air untuk bisa bertahan hidup. Sedangkan sebagai tanda kehidupan mengartikan bahwa di dalam tubuh manusia sebagian besar tersusun oleh air. Sehingga tidak ada air, maka tidak ada pula kehidapan pada manusia. Dengan begitu, dapat dipahami bahwa secara garis besar air merupakan senyawa yang memiliki peran penting dalam mendukung segala sisi kehidupan bagi makhluk hidup yang ada di permukaan Bumi ini, maka diambilah kata dibutuhkan. Karena kata dibutuhkan kurang menarik menjadi kata dari logotype maka kata dibutuhkan diterjemahkan kedalam Bahasa Inggris sehingga menjadi kata NEED. Kata Need juga sangat familiar ditelinga mansyarakat, bahkan yang kurang paham terhadap Bahasa inggris tetap mengetahui arti dari kata need. Selain familiar kata need juga sangat mudah disebut bahkan diingat. Maka jadilah logo terpilih sebagai berikut:

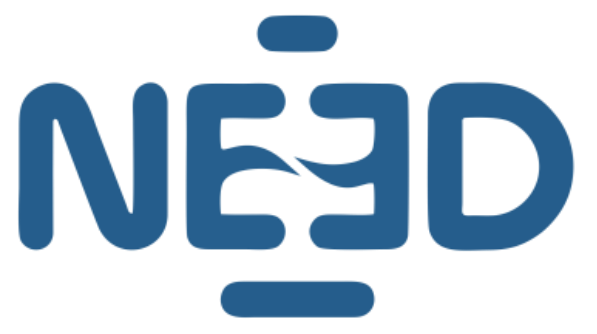

Gambar 4 Logo Terpilih

Icon

Warna Icon yang selaras dengan design warna pada tampilan aplikasi membuat aplikasi terlihat lebih menarik dan modern. 


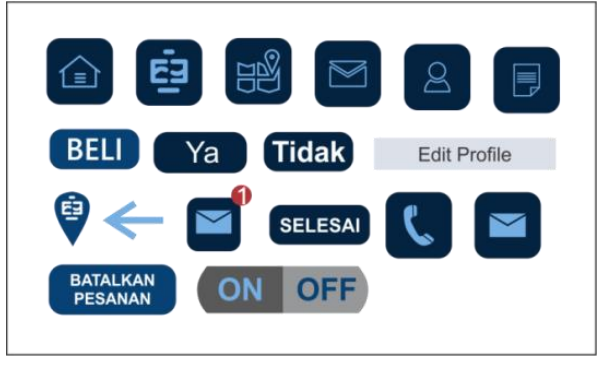

Gambar 5 Icon

\section{Implemetasi Digital}

Dalam hal ini software yang digunakan untuk pembutan desain tampilan aplikasi yaitu Corel Draw, untuk pembuatan logo dan skalanya menggunakan software Adobe Ilustrator dan untuk pembuatan Prototype Aplikasi yang menunjang visual aplikasi digunakan Software Adobe XD. Berikut ialah salah satu contoh penggunaan software.

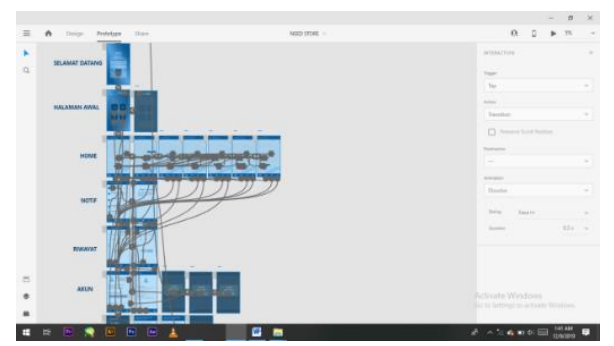

Gambar 6 Pembuatan Prototype Aplikasi menggunakan Adobe XD

\section{Pembahasan}

Berdasarkan langkah-langkah yang dilakukan pada tahap analisa dan konsep desain maka diperoleh hasil berupa visual aplikasi, visual aplikasi ini menghasilkan dua tampilan aplikasi yaitu aplikasi khusus admin dan aplikasi khusus user.

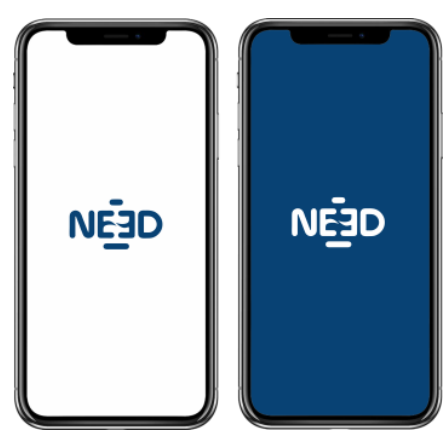

Gambar 7 Aplikasi Admin dan User
Desain Loading Awal untuk User dan Admin

Ketika aplikasi dibuka maka yang terihat adalah visual loading awal pada aplikasi, untuk loading awal user dan admin tampilan visualnya sama yaitu tampak ada logo aplikasi galon yang berada diposisi tengah setelah loading tampak logo aplikasi dan ada tulisan dibawah logo yaitu selamat datang serta table yang wajib diisi untuk masuk ke tampilan selanjuatnya.
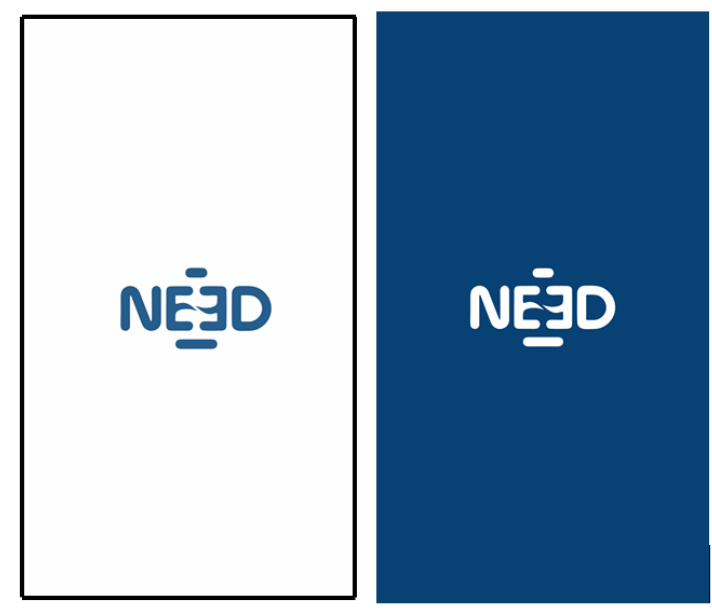

Gambar 8 Loading awal Aplikasi

\section{Desain Loading Selamat Datang}

Setelah loading awal untuk logo maka aplikasi disetting untuk masuk ke halaman selamat datang di halaman ini pengguna wajib memasukkan alamat email dan password yang telah terdaftar untuk loading aplikasi selanjutnya.

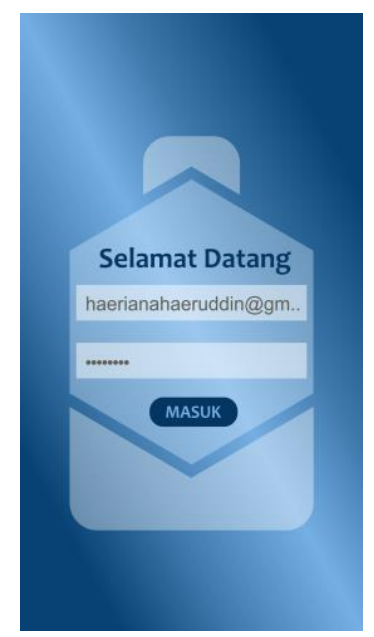

Gambar 9 Loading Selamat Datang 


\section{Desain Halaman Utama untuk Admin dan User}

Di halaman utama User akan terlihat beberapa icon sekaligus sudah menjadi button untuk fitur yang ada pada aplikasi. Di halaman awal user ada empat button mualai dari Pesan, Lokasi, Notif, dan Akun. Sedangkan untuk admin ada empat icon sekaligus sudah menjadi button yaitu, Beranda/home, Notif, Riwayat, dan Akun. Untuk tampilan pada admin ada button khusus untuk on/off toko dimana ketika on toko dinyalakan maka toko otomatis terbuka dan siap menerima pesanan, begitupun sebaliknya ketika button off toko di tekan maka toko tutup dan pemesanan online tidak akan masuk.

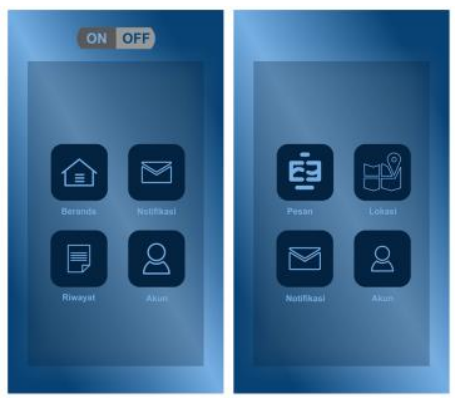

Gambar 10 Halaman Awal Aplikasi Admin Dan User

Desain Menu Beranda untuk Admin

Pada menu beranda terlihat lokasi beberapa depot yang sudah terdaftar pada aplikasi Need.

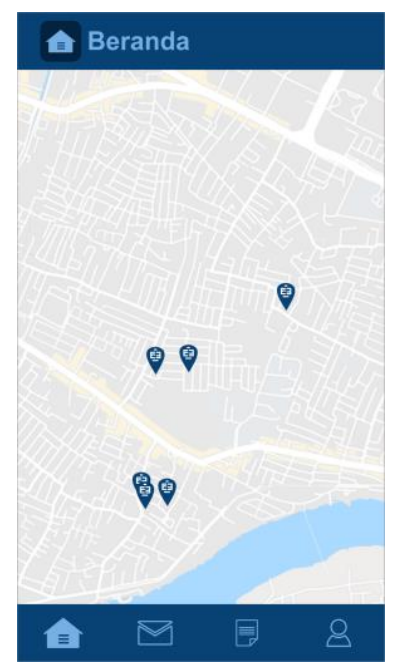

Gambar 11 Menu Beranda pada Admin

\section{Desain Menu Pesan pada User}

Dalam menu ini ada beberapa informasi yang disajikan kepada user berupa informasi toko galon terkait alamat, informasi jam buka dan tutup, dan informasi lain tentang toko galon, ada juga informasi harga untuk penjualan online dan pembelian langsung, disini juga menyediakan informasi rekomendasi toko terdekat dengan lokasi si pemesan.

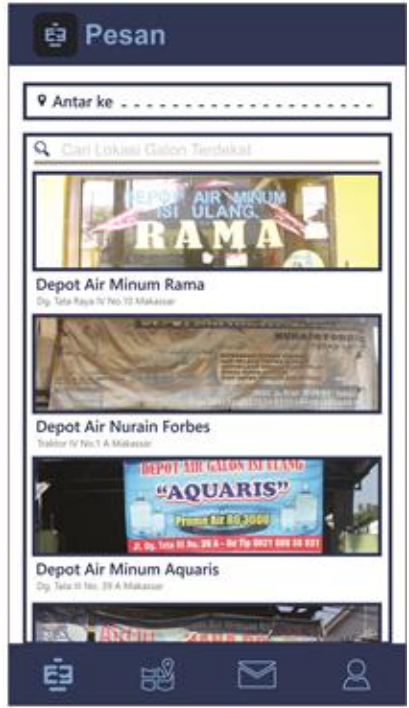

Gambar 12 Menu Pesan pada User

Desain Menu Notifikasi untuk User dan Admin

Menu notifikasi pada aplikasi ini ialah pesan terkait berupa pesanan telah selesai diantar maupun pesan-pesan khusus yang disampaikan user ke admin begitupun sebaliknya.

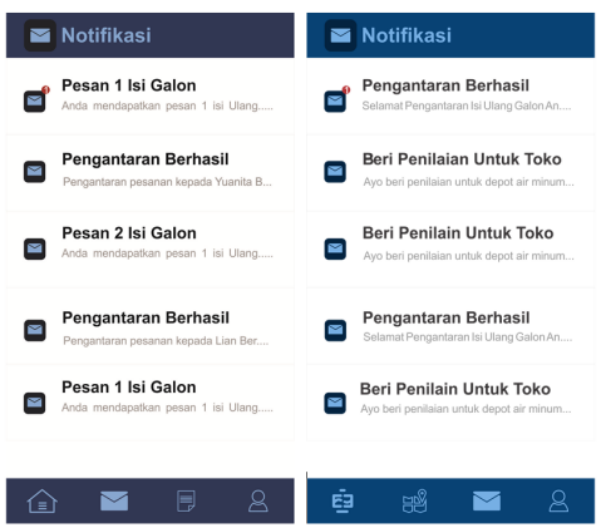

Gambar 13 Menu Notifikasi 


\section{Desain Menu Riwayat untuk Admin}

Didalam menu ini ada informasi data penjualan perhari maupun perbulan.

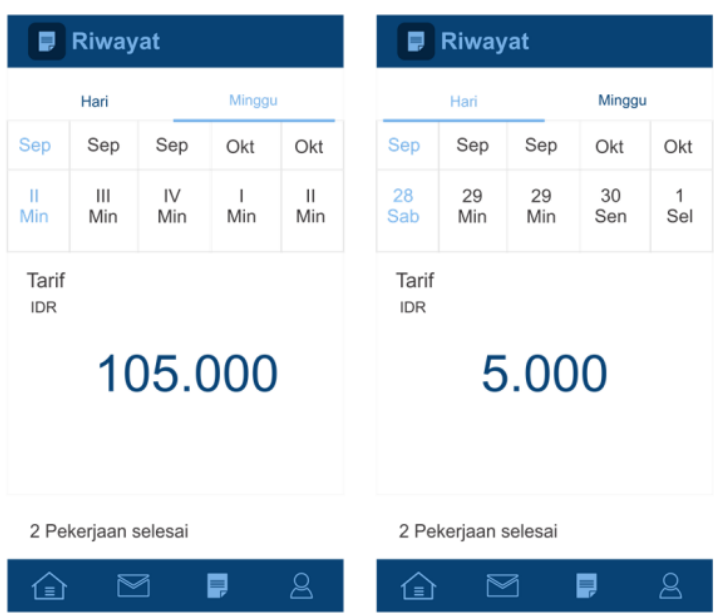

Gambar 14 Menu Riwat pada Admin

Desain Menu Lokasi untuk User

Menu lokasi pada user menampilkan semua lokasi tempat penjualan galon. Ini bisa sangat menguntungkan untuk konsumen yang ingin memebeli langsung ke tempat galon karena bisa menegetahui lokasi galon terdekat dari si konsumen dan tau rute untuk ke penjual galon.

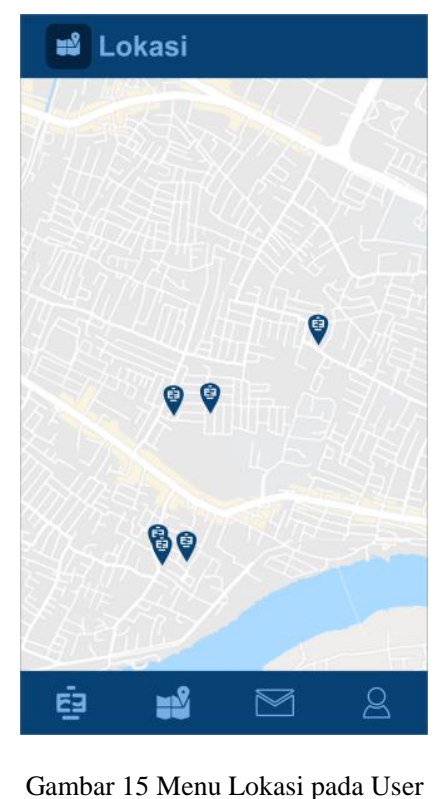

Desain Menu Akun untuk Admin dan User

Untuk menu akun pada admin memuat data profile tempat galon dari nama, alamat serta ada juga informasi pencapaian yang sudah di raih oleh toko galon, sedangkan untuk user memuat data pribadi seperti nama, nomor telpon dan email. Di kedua menu akun admin dan user juga terdapat button untuk keluar dari apikasi.

\section{g Akun}

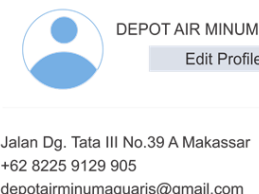

depotaiminumaquaris@gmail.com

Presentasi Pencapaian

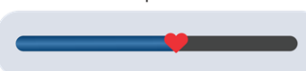

Keluar Dari Aplikasi

\section{Akun}

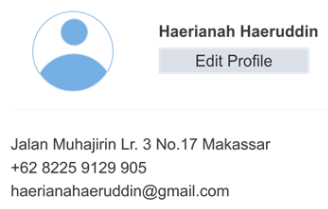

Keluar Dari Aplikas

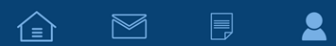

Gambar 16 Menu Akun

\section{Media Pendukung}

Media pendukung yang digunakan dalam perancangan ini ialah media yang mudah ditemuai serta bahan dan pembuatannya ada di Kota Makassar. Berikut adalah beberapa media pendukung yang diaplikasikan.

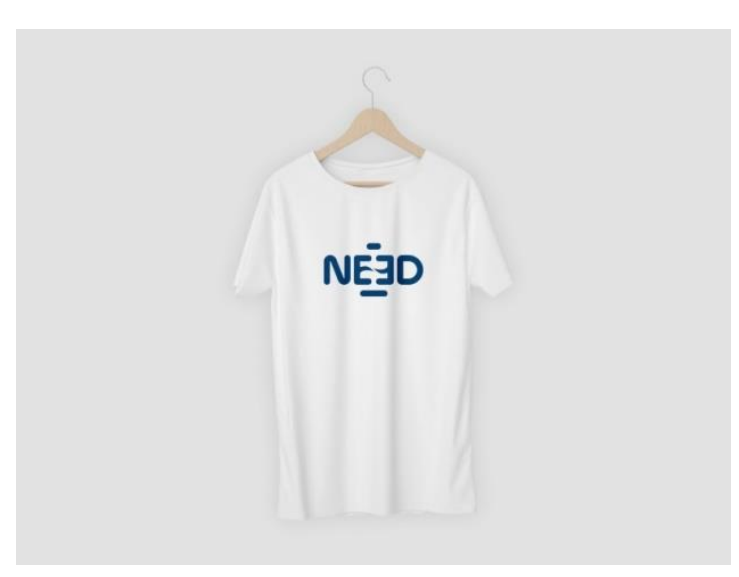

Gambar 17 T-shirt 


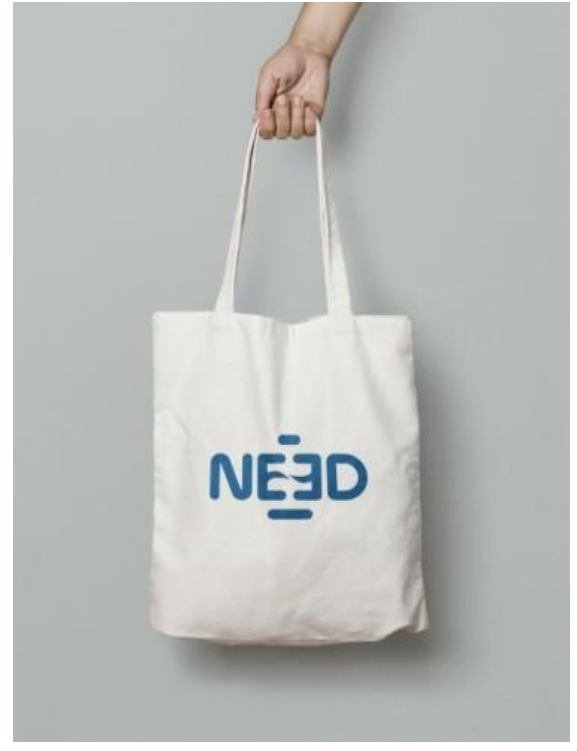

Gambar 18 Totebag

\section{SIMPULAN DAN SARAN Kesimpulan}

Dari awal proses perancangan visual aplikasi pelayanan pengantaran galon di Kota Makassar berbasis android ini memiliki berliku-liku permasalahan, mulai dari observasi remaja yang menggunakan galon hingga mendatangi satu-satu depot air minum di sekitar parangtambung. Ternyata dari beberapa remaja (anak kost) masih banyak yang kesusahan dalam pembelian pengantaran galon dan setelah diteliti lebih dalam lagi media yang cocok pada perancangan ini iyalah aplikasi tapi pada perancangan kali ini lebih merujuk serta menekankan kepada tampilan visual dari aplikasi tersebut. Perancangan kali ini ialah inovasi baru yang belum ada di Kota Makassar. Dalam perancangan sebuah visual aplikasi digital banyak hal yang perlu diperhatikan dalam hal kesesuaian tampilan dengan konsep perancangan, seperti tata letak gambar, elemen-elemen grafis, huruf dan lainnya. Pemilihan media utama yang dihasilkan berupa visual aplikasi sangat relevan digunakan di era digital seperti sekarang ini dimana masyarakat pada umumnya dapat mengakses internet dengan mudah dimanapun dan kapanpun baik melalui smartphone ataupun komputer yang mereka punya. Perancangan ini menghasilkan dua prototype aplikasi yaitu admin dan user. Dan untuk lebih memperkenalkan media yang dirancang perlu media pendukung untuk mempromosikan visual aplikasi.

\section{Saran}

Pada perancangan visual aplikasi pelayanan pengantaran galon di Kota Makassar berbasis android masih belum sempurna dan memiliki banyak kekurangan, oleh karena itu perlu dikembangkan dan penyempurnaan lebih lanjut. Agar visual aplikasi ini lebih baik kedepannya, maka adapun beberapa saran yaitu Dalam penyempurnaan aplikasi ini perlu bekerjasama dengan programmer yang akan membuat aplikasi yang sudah bisa digunakan oleh masyarakat. Pada perancangan ini harus lebih teliti lagi dalam menganalisis serta mngumpulkan data sehingga bisa tervalidasi lebih baik lagi. Sebagai mahasiswa desain komunikasi visual agar kiranya dapat memberikan solusi dari permasalahan yang dihadapi melalui kemampuannya dalam memecahkan masalah-masalah komunikasi melalui visual, tidak terkecuali pada perancangan ini.

\section{DAFTAR PUSAKA}

Djafar, I. (2015). Pembangunan Aplikasi Location Servise (LBS) Kota Makassar. Seminar Nasional Teknologi Informasi Dan Multimedia 2015, 6-8.

Heri. (2017). 13 Arti Warna dan Psikologi Warna, Terlengkap! (Merah, Ungu, Kuning, Hijau, Coklat, Biru dll). Retrieved from Salamadian.com website: https://salamadian.com/artiwarna/

Jogiyanto, H. M. (2017). Analisis dan Desain (Sistem Informasi Pendekatan

Terstruktur Teori dan Praktek Aplikasi Bisnis). Penerbit Andi.

Kotler, P., \& Gary Armstrong. (2008). Prinsip-prinsip Pemasaran (Jilid $1 \mathrm{da}$ ). North Carolina: Jakarta: Erlangga.

Maki, M. (2017). Mengenal Macam-macam Aliran Style Desain Grafis. Retrieved from https://blog.jagodesain.com/ website: https://blog.jagodesain.com/2017/02/styl 
e-desain-grafis.html

Rudi, C. M. (2016). Aplikasi Graf Dalam Menganalisis Potensi Kemacetan di Kota Makassar.

Tinarbuko, I. T. S. (2015). DEKAVE: Desain Komunikasi Visual Penanda Zaman Masyarakat Global. CAPS. 